\title{
METODE PEMBELAJARAN PEER ASSISTED LEARNING PADA PRAKTIKUM ANATOMI
}

\author{
Saharnauli J. Verawaty Simorangkir \\ Departemen Anatomi, Fakultas Kedokteran Universitas HKBP Nommensen
}

\begin{abstract}
Background: Peer Assisted Learning is an active discussion and cooperative learning method within the framework of a partnership in the peer-aged group with the formal structures of the course. PAL is widely seen to be actualised in two modes of operational implementation, which is refer to as "horizontal" and "vertical" peer support. Vertical method was chosen for this research.

Method: This research was used causal-comparative design. Tutees for this research was the students of Faculty of Medicine Universitas HKBP Nommensen from batch 2013 who were undergoing block Respiratory System. Tutees were divided into two groups: 24 students in the control group and 25 students in the treatment group. Both of these group consisted of five tutorial groups in which each group consisted of 4-5 students. Whereas the tutor for the treatment group was 5 students from batch 2011. Pre-test and post-test was given to all of the tutees. This research used a questionnaire modified from Clinical Teaching Preference Questionnaire (CTPQ).

Results: Pre-test and post-test was analyzed using dependent T-test and Wilcoxon, and the result showed that there were significant enhancement for both of group $(p<0,05)$. The result from CTPQ indicated most of the students strongly agree that this method was very helpfull in anatomy lab $(4,40 \pm 0,96)$.

Conclusion: PAL method provided many benefits in learning process including improved social interaction between students and independence in learning.
\end{abstract}

Keyword: peer-assisted learning, anatomy practice lab, tutor, tutee

\section{ABSTRAK}

Latar belakang: Peer Assissted Learning merupakan suatu metode pembelajaran dengan diskusi dengan aktif dan kooperatif dalam suatu kelompok yang seumuran dan tetap mengacu kepada tataan kurikulum. Pada pelaksanaannya, PAL dapat digambarkan dalam dua model yaitu bentuk "horizontal" dan "vertikal".

Metode: Metode yang dipilih pada penelitian ini adalah metode vertikal. Jenis penelitian ini adalah causal-comparative design. Mahasiswa yang bertindak sebagai tutee pada penelitian ini adalah seluruh mahasiswa Fakultas Kedokteran UHKBPN angkatan 2013 yang sedang menjalani Blok Sistem Respirasi. Tutee dibagi dalam 2 kelompok yaitu 24 orang pada kelompok kontrol dan 25 orang pada kelompok perlakuan. Kedua grup ini terdiri dari lima kelompok tutorial yang masing-masing terdiri dari 4-5 orang mahasiswa. Sedangkan yang bertindak sebagai tutor adalah 5 orang mahasiswa angkatan 2011. Seluruh tutee diberikan soal pre-test dan post-test. Penelitian ini menggunakan kuesioner yang telah dimodifikasi dari Clinical Teaching Preference Questionnaire (CTPQ).

Hasil: Hasil pre-test dan post-test pada kedua kelompok berdasarkan analisis dengan menggunakan uji $\mathrm{T}$ berpasangan dan uji Wilcoxon sama-sama menunjukkan peningkatan yang signifikan $(\mathrm{p}<0,05)$. Hasil CTPQ menunjukkan bahwa sebagian besar mahasiswa sangat setuju bahwa metode PAL ini sangat membantu dalam praktikum anatomi $(4,40 \pm 0,96)$.

Kesimpulan: Metode PAL memberikan banyak manfaat dalam proses belajar mengajar termasuk di dalamnya meningkatkan interaksi sosial antara mahasiswa dan kemandirian dalam belajar.

Kata kunci : peer-assisted learning, laboratorium, praktikum anatomi, tutor, tutee

korespondensi: vera_nommie@yahoo.com 


\section{PENDAHULUAN}

Fakultas Kedokteran Universitas Huria Kristen Batak Protestan Nommensen (UHKBPN) berdiri sejak tahun 2009 dan sejak berdirinya telah menerapkan Kurikulum Berbasis Kompetensi (KBK) yang besifat terintegrasi. Pandangan baru yang ingin dibangun selama proses pembelajaran dengan kurikulum ini adalah bahwa dosen tidak lagi menjadi sumber utama yang akan mentransferkan seluruh ilmu pengetahuannya kepada mahasiswa, justru sebaliknya mahasiswa diharapkan memperoleh pengetahuannya dengan menjadikan dirinya sebagai 'sumber utama' bagi dirinya sendiri. ${ }^{1}$ Empat kegiatan utama dalam pelaksanaaan strategi pembelajaran dan pengajaran di Fakultas Kedokteran UHKBPN yaitu teori (kuliah), tutorial, skills lab dan praktikum. Praktikum anatomi adalah salah satu praktikum biomedik yang selalu ada hampir dalam setiap blok dan diakui sebagai salah satu ilmu preklinis yang sangat penting.

Selamabertahun-tahun, ilmuanatomidiajarkansecara tradisional, dimana dosen yang aktif memberikan pengajaran pada waktu kuliah, sedangkan mahasiswa hanya sebagai pendengar, kemudian dilanjutkan dengan kegiatan diseksi kadaver. Metode pengajaran ini dirasakan kurang efektif untuk menyampaikan materi secara konseptual dalam waktu yang singkat. ${ }^{2}$ Ditambah lagi dengan semakin meningkatnya jumlah mahasiswa kedokteran setiap tahunnya, sementara tenaga pendidik yang tersedia terbatas, juga semakin tingginya tingkat kompetensi yang dituntut dari seorang dokter, hal ini mendorong berkembangnya berbagai variasi metode mengajar, yang salah satunya adalah metode Peer Assisted Learning (PAL). ${ }^{3}$ PAL merupakan suatu metode pembelajaran dimana mahasiswa dapat berdiskusi dengan aktif dan kooperatif. Proses pembelajaran dengan diskusi aktif dan kooperatif ini menurut Capstick dapat digambarkan dalam dua metode yaitu bentuk horizontal dan vertikal. Metode horizontal dimaksudkan bahwa mahasiswa seangkatan yang bertindak sebagai tutor, sedangkan pada metode vertikal, mahasiswa yang lebih senior yang berperan sebagai tutor. ${ }^{4}$ Terdapat beberapa istilah dalam metode ini yaitu, tutor adalah mahasiswa yang berperan sebagai dosen yang mengajar ataupun yang memberikan penilaian, dan tutee adalah mahasiswa yang diajar atau diberi penilaian ${ }^{3}$
Di Fakultas Kedokteran UHKBPN sendiri, masih banyak kendala yang dihadapi dalam proses pengajaran Anatomi, baik dari segi Sumber Daya Manusia (SDM) maupun sarana dan prasarana. SDM di bagian Departemen Anatomi sampai saat ini hanya terdiri dari 3 orang dosen dimana 2 diantaranya masih dalam masa pendidikan magister, dibantu oleh seorang laboran yang bertugas membantu mempersiapkan peralatan praktikum. Jadwal kuliah anatomi sendiri dalam setiap blok minimal 4 jam, ditambah dengan jadwal praktikum untuk dua kelompok besar mahasiswa dan masingmasing kelompok mendapat jadwal minimal 2 jam. Terbatasnya jumlah SDM bila dibandingkan dengan banyaknya topik yang harus disampaikan dan besarnya jumlah mahasiswa, menjadi permasalahan yang telah lama dihadapi di Departemen Anatomi. Oleh karena itu, perlu dikembangkan metode belajar-mengajar yang lebih efektif dan mampu mengatasi kendala yang ada. PAL dengan metode vertikal merupakan metode yang dirasa cukup efektif untuk diterapkan di dalam kegiatan praktikum anatomi. Implementasi metode PAL akan dilakukan pada sistem kurikulum blok VII yaitu blok respirasi yang dijadwalkan akan dilaksanakan pada semester III. Berdasarkan penjelasan di atas, peneliti tertarik untuk mengetahui manfaat penerapan metode PAL dalam kegiatan praktikum Anatomi di Fakultas Kedokteran UHKBPN dan bagaimana persepsi mahasiswa mengenai metode ini.

\section{METODE}

Sampel penelitian ini adalah seluruh mahasiswa Fakultas Kedokteran UHKBPN angkatan 2013 yang sedang menjalani Blok Sistem Respirasi, yaitu sebanyak 49 orang. Seluruh sampel penelitian dibagi secara acak ke dalam dua kelompok yaitu 24 orang untuk kelompok kontrol dan 25 orang untuk kelompok perlakuan.

Perekrutan mahasiswa yang bertindak sebagai tutor dalam penelitian ini dilakukan secara sukarela. Tutor dipilih dari mahasiswa kedokteran UHKBPN angkatan 2011 yang memiliki nilai akademis yang baik, khususnya bidang anatomi, telah lulus seleksi tertulis dan wawancara dan juga telah berpengalaman menjadi asisten laboratorium anatomi minimal 6 
bulan. Jumlah tutor yang digunakan pada penelitian ini yaitu sebanyak 5 orang.

Sebelum praktikum dimulai, setiap kelompok penelitian, baik kelompok kontrol maupun kelompok perlakuan diberikan soal pre-test berupa 10 buah pertanyaan dalam bentuk power point, dan setiap soal akan diatur bergantian secara otomatis setiap 1 menit. Praktikum dilaksanakan selama 2 jam 30 menit, dengan alokasi waktu 10 menit untuk pre-test, 2 jam untuk praktikum dan 20 menit untuk pengisian kuesioner dan post-test. Seluruh kelompok kontrol dan kelompok perlakuan dibagi menjadi 5 kelompok sesuai dengan jumlah tutor. Setiap tutor diberi label pada mejanya berupa nomor 1 sampai 5, dan setiap perputaran diberi waktu sekitar 25 menit, kemudian setelah waktu habis, tutee akan berpindah ke nomor tutor yang berikutnya secara berurutan. Demikian seterusnya sampai 5 putaran untuk masing-masing kelompok tutee. Pada akhir praktikum, seluruh kelompok kontrol maupun kelompok perlakuan akan diberikan post-test dengan soal dan metode yang sama dengan pre-test. Sedangkan kuesioner hanya diberikan kepada kelompok perlakuan. Selanjutnya hasil pre-test dan post-test akan dianalisa secara statistik dengan uji $\mathrm{T}$ berpasangan dan hasil kuesioner akan dianalisa dalam bentuk deskriptif kuantitatif.

\section{HASIL DAN PEMBAHASAN}

Uji reliabilitas kuesioner pada penelitian ini dilakukan pada 30 orang responden yang memiliki kriteria yang sama dengan subjek penelitian, pemilihan jumlah ini dengan alasan lebih mendekati kurva normal. Mahasiswa yang dipilih sebagai responden untuk uji reliabilitas adalah mahasiswa angkatan
2012 yang telah melaksanakan metode PAL sebanyak dua kali pada praktikum anatomi. Kuesioner ini telah diterjemahkan ke dalam bahasa Indonesia dan telah divalidasi. Hasil pre-test dan post-test pada kelompok kontrol terlihat pada tabel 1 .

Tabel 1. Rerata Hasil Pre-test dan Post-test Kelompok Kontrol

\begin{tabular}{ccc}
\hline Jenis data & Jumlah $(\mathbf{n})$ & Ratarata \pm SD \\
\hline Pre-test & 24 & $40 \pm 25,54$ \\
Post-test & 24 & $67,08 \pm 24,58$ \\
\hline
\end{tabular}

Hasil uji $\mathrm{T}$ berpasangan diperoleh nilai kemaknaan p $<0,05$ untuk kedua hasil di atas, artinya terdapat perbedaan rerata pre-test dan post-test pada kelompok kontrol.

\section{Tabel 2. Rerata Hasil Pre-test dan Post-test} Kelompok Perlakuan

\begin{tabular}{ccc}
\hline Jenis data & Jumlah (n) & Ratarata \pm SD \\
\hline Pre-test & 25 & $28,40 \pm 25,28$ \\
Post-test & 25 & $76,80 \pm 18,87$ \\
\hline
\end{tabular}

Hasil pre-test dan post-test pada kelompok perlakuan terlihat pada tabel 2 .

Hasil uji Wilcoxon diperoleh nilai kemaknaan $p<0,05$, artinya terdapat perbedaan rerata pre-test dan post-test pada kelompok perlakuan.

Bagian pertama (pernyataan no.1-9) dari kuesioner CTPQ akan mengeksplorasi mengenai bagaimana persepsi mahasiswa mengenai penerapan PAL. Hasil perhitungan untuk pertanyaan-pertanyaan bagian pertama ini dapat dilihat pada tabel 3. 
Tabel 3. Persepsi Mahasiswa Mengenai Penerapan PAL

Pertanyaan

Saya lebih merasa nyaman menunjukkan kemampuan saya di depan asisten praktikum dibandingkan di hadapan dosen saya

Interaksi dan kerja sama antara saya dan teman-teman lebih banyak terjadi pada saat saya diajar ol eh asisten praktikum dibandingkan saat diajar oleh dosen saya

Saya lebih bebas berkomunikasi dengan asisten praktikum dibandingkan dengan dosen saya

Penggunaan asisten selama pelaksanaan praktikum lebih banyak membantu saya dalam belajar dibandingkan ketika hanya dosen saya yang mengajar

Saya lebih percaya diri dan merasa mampu melaksanakan tugas tugas praktikum secara mandiri ketika diajar oleh asisten praktikum dibandingkan dengan dosen saya

Tanggapan tentang saya, yang saya terima dari asisten praktikum lebih realistis dan jujur dibandingkan dengan dosen saya, karena berasal dari pandangan sesama mahasiswa.

Kemampuan saya untuk menyelesaikan kasus yang berkaitan dengan bidang anatomi lebih baik ketika diajar oleh dosen saya dibandingkan dengan asisten praktikum (misalnya dalam tutorial)

Saya memperoleh ilmu yang lebih banyak dari dosen saya dibandingkan dari asisten praktikum

Saya lebih le luasa meminta bantuan dalam melaksanakan tugas dari dosen saya dibandingkan dengan asisten praktikum

\section{N Rerata \pm SD}

$25 \quad 3,64 \pm 0,91$

$25 \quad 4,04 \pm 0,89$

$25 \quad 4,32 \pm 0,69$

$25 \quad 4,40 \pm 0,96$

$25 \quad 3,88 \pm 0,97$

$25 \quad 2,96 \pm 1,21$

$25 \quad 3,32 \pm 1,11$

$25 \quad 3,20 \pm 1,16$

$25 \quad 2,80 \pm 0,91$

Bagian kedua (pernyataan no.10) akan mengevaluasi pertanyaan-pertanyaan bagian pertama ini dapat sejauh mana manfaat penerapan metode PAL ini dilihat pada tabel 4 di bawah ini. dirasakan oleh mahasiswa. Hasil perhitungan untuk

Tabel 4. Hasil Evaluasi mengenai Manfaat Penerapan PAL

\begin{tabular}{llc}
\multicolumn{1}{c}{ Pertanyaan } & N & Rerata \pm SD \\
$\begin{array}{llc}\text { Metode belajar Peer-Assisted Learning lebih membuat saya } & 25 & 4,20 \pm 0,82 \\
\text { bertanggung jawab atas hasil yang saya capai dalam pembelajaran } \\
\text { ini (nilai yang saya capai tergantung pada saya bukan pada dosen } \\
\text { saya) }\end{array}$ & \\
\hline
\end{tabular}


Fakultas Kedokteran UHKBPN sebagaimana fakultas kedokteran lainnya dalam perkembangannya terus melakukan pembenahan serta peningkatan mutu pendidikan di segala bidang demi menghasilkan dokter-dokter yang berkualitas dan berkompetensi tinggi dalam bidang ilmu kedokteran. Dalam bahasa latin, kata dokter berarti guru. Seorang dokter harus mampu bertindak sebagai "guru", guru bagi pasiennya dalam hal memberi penjelasan mengenai hasil diagnosis penyakit dan rencana penatalaksanaan dan guru bagi sejawat dalam pendidikan spesialisasi. Meskipun begitu besar peranannya, pengajaran mengenai bagaimana menjadi seorang "guru" belum menjadi bagian dari kurikulum pendidikan kedokteran, oleh karena itu perlu dikembangkan metode yang dapat membantu mahasiswa kedokteran menjadi "guru" yang baik.

Peer Assissted Learning (PAL) merupakan suatu metode pembelajaran dimana mahasiswa dapat berdiskusi dengan aktif dan kooperatif dan tetap mengacu kepada target kurikulum. ${ }^{4}$ Pada penelitian ini digunakan PAL dengan metode vertikal dimana yang bertindak sebagai tutor adalah mahasiswa yang lebih senior yang berasal dari angkatan 2011 dan yang berperan sebagai tutee adalah mahasiswa angkatan 2013. Hasil pre-test dan post-test pada kedua kelompok berdasarkan analisa dengan menggunakan uji $\mathrm{T}$ berpasangan dan uji Wilcoxon sama-sama menunjukkan peningkatan yang signifikan ( $p>$ 0,05), dengan kata lain bahwa perbedaan metode pengajaran pada pelaksanaan praktikum anatomi tidak memberikan perbedaan yang bermakna pada pencapaian nilai akademik.

Beberapa penelitian mengenai metode pembelajaran PAL menunjukkan hasil yang cukup beragam. Penelitian mengenai penerapan metode PAL pada praktikum anatomi dengan menggunakan cadaver memberikan hasil yang positif dimana terdapat peningkatan nilai ujian yang signifikan antara sebelum dan sesudah pelaksanaan PAL pada seluruh angkatan (2008-2010) yang menjadi sampel penelitian. Sekitar 90\% mahasiswa yang terlibat dalam penelitian ini setuju bahwa metode PAL ini dapat meningkatkan pemahaman mereka tentang bidang ilmu yang dipelajari. ${ }^{2}$ Hasil yang lain oleh Adekoya, dkk yang melakukan penelitian pada siswa-siswi Sekolah Menengah Atas (SMA) di Nigeria tepatnya di negara bagian Ogun, penelitian ini dilakukan pada mata pelajaran ilmu pertanian dengan menggunakan tiga metode pembelajaran yaitu metode kuliah di kelas, metode PAL dan metode demonstrasi. Hasil yang diperoleh menunjukkan bahwa tidak terdapat perbedaan nilai akademik yang signifikan antara metode kuliah di kelas dan metode PAL. ${ }^{3}$

Adekoya berpendapat bahwa efektivitas PAL dalam proses belajar mengajar tidak banyak memberi pengaruh kepada pencapaian nilai akademik akan tetapi lebih kepada learning process termasuk di dalamnya interaksi sosial antara mahasiswa dan kemandirian mahasiswa dalam belajar. ${ }^{7}$ Penelitian lain yang menerapkan metode PAL pada praktikum anatomi gigi di fakultas kedokteran gigi Universitas Kentucky juga menunjukkan hasil rata-rata nilai ujian praktikum yang tidak berbeda secara signifikan antara kelompok perlakuan dan kelompok kontrol. Banyak faktor yang diperkirakan mungkin dapat mempengaruhi nilai ujian antara lain jenis kelamin, usia dan asal angkatan mahasiswa atau bisa dikatakan lama menjalani studi sebagai mahasiswa kedokteran. ${ }^{8}$

Selain penilaian mengenai hasil akademik, peneliti-an ini juga mengevaluasi persepsi mahasiswa mengenai metode PAL dengan menggunakan kuesioner hasil modifikasi dari Clinical Teaching Preference Questionnaire (CTPQ). Pada penelitian ini mahasiswa-mahasiswi memberikan respons yang positif terhadap penerapan metode ini, dimana sebagian besar dari mereka sangat setuju bahwa metode PAL ini sangat membantu dalam praktikum anatomi $(4,40 \pm 0,96)$. Selain itu mahasiswa juga setuju bahwa melalui penerapan PAL di dalam praktikum anatomi dapat menciptakan komunikasi yang lebih bebas, lebih nyaman, lebih aktif dan mahasiswa merasa lebih percaya diri dalam menunjukkan kemampuan mereka di hadapan para tutor. Menurut Longareth, $\mathrm{dkk}$, penerapan metode PAL dapat meningkatkan motivasi, mengembangkan kemampuan kognitif dan bersosialisasi. Metode ini terbukti dapat menjembatani kebutuhan akan peningkatan nilai akademik dan pengembangan kemampuan bersosialisasi mahasiswa pada berbagai bidang ilmu. ${ }^{7}$ Metode PAL juga telah diterapkan pada sekolah pelatihan untuk para atlit, dan hasilnya 
menunjukkan bahwa siswa-siswi merasa lebih tenang, lebih percaya diri dan lebih komunikatif selama proses pembelajaran. ${ }^{9}$

Hasil evaluasi kuesioner pada penelitian ini menunjukkan bahwa sebagian besar mahasiswa tidak merasakan perbedaan yang signifikan antara tutor dan dosen mengenai pemberian feedback, pemahaman dan perolehan ilmu serta kebebasan meminta bantuan selama praktikum berlangsung. Hal ini kemungkinan dapat disebabkan adanya rasa 'segan' sebagai junior terhadap tutor yang lebih senior, dimana hal ini merupakan kelemahan dari metode PAL bentuk vertikal. Pada metode horizontal, dimana kondisi pembelajaran difasilitasi oleh teman sebaya yang akrab sehingga akan membuat tutee mengikuti kegiatan pembelajaran dengan lebih efektif, karena mahasiswa akan lebih leluasa untuk mengatur waktu pembelajaran, tujuan-tujuan belajar dan target penguasaan materi yang diharapkan. ${ }^{10}$

Berbeda dengan hasil yang dikemukakan oleh Henning, dkk bahwa penerapan metode PAL di sekolah pelatihan atlet dirasakan lebih memberikan pemahaman skill yang banyak dibandingkan dengan hanya dibimbing oleh seorang pelatih. Para siswa ini juga berpendapat bahwa feedback yang diberikan oleh para tutor yang lebih senior lebih banyak membantu dan lebih realistis dibandingkan feedback yang berasal dari para pelatih, sebagai contoh para siswa dapat dengan leluasa menanyakan pendapat tutor mereka mengenai gerakan-gerakan tertentu atau bagaimana sebagai atlet dapat segera pulih bila mengalami cedera. $^{7}$ Sedangkan menurut hasil penelitian yang dilakukan pada praktikum anatomi di fakultas kedokteran gigi Universitas Kentucky, sekitar 45,6\% mahasiswa merasakan adanya peningkatan pemahaman materi praktikum, sekitar $34,4 \%$ berpendapat bahwa metode ini tidak memberikan efek apapun dalam proses belajar mereka, bahkan 20\% dari mahasiswa berpendapat metode ini mengganggu jalannya proses belajar mengajar. ${ }^{8}$

Hasil evaluasi bagian kedua (pernyataan no.10) dari CTPQ mengenai manfaat dari metode PAL ini adalah sebagian besar mahasiswa setuju bahwa melalui metode ini rasa tanggung jawab mereka atas pemahaman materi dan pencapaian nilai akademik lebih meningkat $(4,20 \pm 0,82)$. Hal ini sejalan dengan hasil penelitian yang diperoleh Longareth, dkk dimana metode ini dapat meningkatkan rasa tanggung jawab mahasiswa terhadap proses pembelajarannya. ${ }^{9}$

Kekurangan dari penelitian ini adalah faktor-faktor yang dapat mempengaruhi proses belajar mengajar seperti jenis kelamin, asal angkatan, tidak dianalisa lebih jauh, sehingga tidak dapat dijelaskan dengan lebih terperinci faktor-faktor lain yang mungkin ikut mempengaruhi hasil penelitian ini. Selain itu juga persepsi dari para tutor tidak diteliti sehingga kita tidak mendapat gambaran mengenai manfaat metode ini bagi mahasiswa yang bertindak sebagai pengajar.

\section{KESIMPULAN}

Perbedaan metode pengajaran pada pelaksanaan praktikum anatomi tidak memberikan perbedaan yang bermakna pada pencapaian nilai akademik, akan tetapi penerapan metode PAL ini mendapat respon yang positif dari mahasiswa.

\section{DAFTAR PUSTAKA}

1. Gwee MC. Problem-Based Learning : A Strategic Learning System Design for The Education of healthcare Professionals in The 21st Century. Kaohsiung J Med Sci [Internet]. Elsevier; 2009;25(5):231-9.

2. Waghmare JE, Sontakke BR, Tarnekar AM, Bokariya P, Wankhede V, Shende MR. Reciprocal peer teaching : an innovative method to learn gross anatomy. J Mahatma Gandhi Institue. 2010;15(ii):403.

3. Burgess A, Mcgregor D, Mellis C. Medical students as peer tutors : a systematic review. BMC Med Educ. 2014;14(1):1-8.

4. Green P. In and beyond the classroom A Literature Review of Peer Assisted Learning ( PAL ). National HE STEM Programme. 2011. p. 1-8.

5. Bulte C, Betts A, Garner K, Durning S. Student teaching: views of student near-peer teachers and learners. Med Teach. 2007;29:583-90.

6. Yu T, Wilson N, Singh P, Lemanu D, Hawken S, Hill A. Medical students-as-teachers : a systematic review of peer-assisted teaching during medical school. Adv Med Educ Pract. 2011;2:157-72. 
7. Adekoya YM, Olatoye RA. Effect of Demonstration , Peer-Tutoring , and Lecture Teaching Strategies on Senior Secondary School Students 'Achievement in an Aspect of Agricultural Science . Pacific J Sci Technol. 2011;12(1):320-32.

8. Brueckner JK, Macpherson BR. Benefits from peer teaching in the dental gross anatomy laboratory. Eur J Dent Educ. 2004;8:72-7.
9. Morris M. Athletic Training Students' Perceptions of Peer-Assissted Learning in The Classroom and Nonclassroom Settings. 2008. p. 81-2.

10. Arjanggi R. Metode Pembelajaran Tutor Teman Sebaya Meningkatkan Hasil Belajar Berdasar Regulasi Diri. Makara Sains. 2010;14(2):91-7. 